\title{
Delo wins third place in the customer champions competition
}

In the German Customer Champions Competition 2013, Delo Industrie Klebstoffe won third place in the main category of "Best medium-sized company". More than 100 organisations took part.

Fiñ

r the sixth time the forum! institute

together with the Deutsche Gesellschaft für Qualität e.V. (DGQ) (German Society for Quality), has analysed and compared the quality of customer relationships at German companies as part of a nationwide benchmarking study covering a number of industries. The German Customer Champions competition is based on a representative customer survey.

The award was presented to Christian Walther, sales director for Germany, during a formal ceremony in the historic rooms of the Kupferbergterrasse in Mainz. "Ranking among the three best mediumsized companies means that our work really has been recognised," said Christian Walther. "Our customers are particularly impressed by the reliability, friendliness and expertise of Delo's employees."

In addition, the customers rated the product quality, logistics and delivery capability of the company as being above average. "The results show that we are clearly above average in terms of

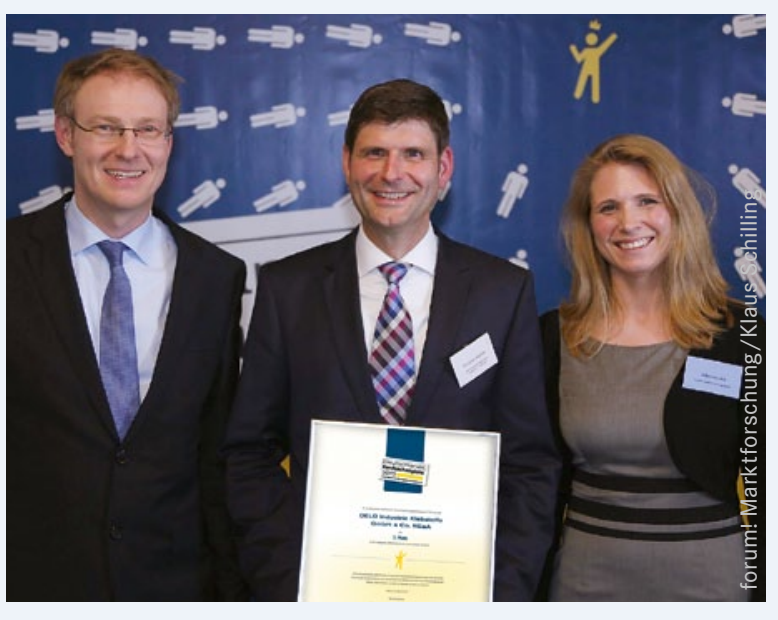

Roman Becker, managing director of forum! Marktforschung, Christian Walther, Delo sales director in Germany and Deborah Leib, senior project manager at forum! Marktforschung at the award ceremony (left to right). the attributes 'very professional', 'very reliable' and 'very innovative'," added Christian Walther. The company's performance in the areas of customer focus and complaints management also achieved positive results. Third place in this competition is the second award that Delo, which is based in the German town of Windach, has won in the space of only a week. On 24 April, Delo was officially recognised as a "great place to work" and, therefore, is among the 20 best employers in Germany in the category 50 to 500 employees. Around 500 companies took part in the competition.

\section{Butanediol from renewable feedstock}

$\mathrm{B}$ ASF plans to begin production of 1,4-butanediol from renewable feedstock (renewable BDO) using the patented process developed by Genomatica from San Diego, California. The one-step fermentation process is based on sugars as a renewable raw material.

The licence agreement allows BASF to build a world-scale production facility that will use the Genomatica process to manufacture BDO using renewable feedstock. Genomatica will continue to enhance its patented sugarbased production process, while BASF will produce renewable BDO, which will be available in the second half of 2013 for sampling and trials.

BASF currently produces BDO and BDO-equivalents at its sites in Ludwigshafen in Germany, Geismar in Louisiana, Chiba in Japan, Kuantan in Malaysia and Caojing in China, and has an annual capacity of 535,000 tonnes. BASF has recently announced its intention of building a BDO complex in China with an annual capacity of 100,000 tonnes.

\section{Behn Meyer distributes Perkacit products}

B ehn Meyer Europe $\mathrm{GmbH}$ is taking over the distribution rights for the Perkacit brand of dithiocarbamate accelerators and the thiuram TBzTD for rubber, latex and adhesives in Germany, Austria and Switzerland from $1 \mathrm{Ju}-$ ly 2013. Behn Meyer is already responsible for the distribution of these products in Eastern Europe and Scandinavia.

Perkacit products are manufactured by Performance Additives Italy S.P.A., which has its headquarters in Termoli in Italy, and are used as antioxidants and accelerators for rubber-based formulations in the adhesives industry. 